\title{
ARAŞTIRMA / RESEARCH \\ Cerrahi süreçteki sağlık profesyonellerinin kişilerarası iletişim tarzları ve ekip çalışması tutumları
}

Interpersonal communication styles and team work attitudes of health professionals in surgical process

\author{
Aslı Saldamlı1D, Ișıl Ișı1k Andsoy²(D)
}

${ }^{1}$ Bartın Üniversitesi, Sağlık Hizmetleri Meslek Yüksekokulu, Tibbi Hizmetler ve Teknikleri Bölümü, Bartın, Turkey

${ }^{2}$ Karabük Üniversitesi, Sağılı Bilimleri Fakültesi, Hemşirelik Bölümü, Cerrahi Hastalıkları Hemşireliği, Karabük, Turkey

\begin{abstract}
Cukurova Medical Journal 2019;44(Suppl 1):483491.
Abstract

Purpose: The purpose of the study is to evaluate the attitudes of the health professionals who are part of the surgical procedure, towards interpersonal relationship styles and team work.

Materials and Methods: This study was descriptive type. The 126 surgical team members were participated in this study. The data were collected by "Personal Information Form", "Interpersonal Communication Style Scale (ICSS)" and "Teamwork Attitudes Scale (TAS)".

Results: The lowest score of the total mean scores of the TAS was obtained by the nurses and the highest score of the total mean scores of TAS and ICSS were obtained by the other health professionals, and that the lowest score of the TAS communication sub-scale was obtained by the physicians. It was determined that the mean scores of the other health professionals obtained from ICSS avoidant sub-scale were significantly higher than the mean scores of nurses and their mean scores obtained from TAS communication sub-scale were significantly higher than the mean scores of nurses and physicians. The mean scores obtained from ICSS dominant style sub-scale of the team members who had worked for 21 years and over, were found to be significantly higher than the other team members.

Conclusion: In this direction, it is recommended to plan trainings aimed at improving interpersonal

\section{$\ddot{O}_{z}$}

Amaç: Araştırmanın amacı, cerrahi girişim sürecinde yer alan sağlık profesyonellerinin kișilerarası ilișki tarzları ve ekip çalışmasına yönelik tutumlarının değerlendirilmesidir. Gereç ve Yöntem: Araştırma tanımlayıcı tiptedir. Örnekleme gönüllü 126 cerrahi ekip üyesi alındı. Veriler "Kişisel Bilgi Formu", "Kişilerarası İletişim Tarzları Ölçeği (KİTÖ)" ve "Ekip Çalışması Tutumları Ölçeği (EÇTÖ)" ile topland.

Bulgular: Çalışmada EÇTÖ'den en düşük puanı hemşirelerin, EÇTÖ ve KİTÖ'den en yüksek puanı ise diğer sağlık profesyonellerinin aldığ saptandı. Yine EÇTÖ'nün iletişim alt boyutundan en düşük puanı alan hekimlerdi. Diğer sağllk profesyonellerinin, KİTÖ’nün kaçıngan tarz alt boyutundan aldıkları puan ortalamasının hemșirelere göre anlamlı derecede yüksek, ECTÖ'nün iletişim alt boyutundan aldıkları puan ortalamalarının hemșire ve hekimlere göre anlamlı derecede yüksek olduğu belirlendi. Çalışmada 21 yıl ve üzeri çalışan cerrahi ekip üyelerinin KİTÖ'nün baskın tarz alt boyutundan aldıkları puan ortalamasının daha az süre çalışan ekip üyelerine göre anlamlı derecede yüksek olduğu bulundu.

Sonuç: $\mathrm{Bu}$ doğrultuda cerrahi ekip üyelerine yönelik kişilerarası iletişim becerilerini ve ekip çalışması tutumlarını geliștirmeye yönelik eğitimlerin planlanması, var olan sorunların saptanması, giderilmesine yönelik bireysel ve kurumsal girişimlerin yapılması önerilmektedir.
\end{abstract} communication skills and teamwork attitudes towards surgical team members, and to make individual and institutional initiatives to overcome existing problems.

Keywords: Surgical team, communication style, teamwork, attitude
Anahtar kelimeler: Cerrahi ekip, iletişim tarzı, ekip çalışması, tutum

Yazışma Adresi/Address for Correspondence: Dr. Işıl Işık Andsoy, Karabük Üniversitesi, Sağlık Bilimleri Fakültesi, Hemşirelik Bölümü, Cerrahi Hastalıkları Hemşireliği, Karabük, Turkey E-mail: isilandsoy@karabuk.edu.tr)

Geliș tarihi/Received: 24.04.2019 Kabul tarihi/Accepted: 23.08.2019 Çevrimiçi yayın/Published online: 27.09.2019 


\section{GİRİŞ}

Kişilerarası iletişim kültürel, duygusal ve bilişsel değişkenlere sahip çift yönlü, aktif bir süreçtir ${ }^{1}$. Bireylerin kişilerarası iletişimini etkileyen faktörler ve çevresiyle olan etkileşimi kişilerarası iletissim tarzlarını oluşturmaktadır ${ }^{2}$. Diğer yandan, kişilerin çevreleriyle kurdukları ilişkiler de yaşamdan aldıkları zevk ve mutluluklarını etkilemektedir. İletişim becerilerinin yetersiz olduğu durumlarda, yalnızlık, stres, mutsuzluk, tatminsizlik, aile içi ve mesleki sorunlar ile fiziksel hastalıklar görülebilmektedir ${ }^{3}$.

İletişim şekillerinden biri olan ekip iletişimi, belli bir amaç için belirli süre içerisinde bir araya gelen bireylerin iletişimini içermektedir. Ekip iletişiminin oldukça önem kazandığı alanlardan birisi de sağlık hizmetleridir. Sağlık hizmetlerinde ekip kavramı, hastanın kaliteli sağlık hizmeti alması amacıyla farklı sağlık profesyonellerinin yer aldığı anti-hiyerarşik yap1 olarak tanımlanmakta olup, hasta ve çalışan güvenliğinin sürdürülmesi açısından gereklidir. Her ekip üyesinin görev tanımı farklı ve aynı derecede önemlidir ${ }^{4,5}$. Sağlık ekibi üyeleri birbirinin yardımcısı değil tamamlayıcısıdır. Çalışmalarda, etkin ekip iletişimi sağlamış gruplarda, ekip üyelerinin görev ve sorumluluklarını daha iyi anladıkları, yaşanılan sorunları kolaylıkla çözdükleri, bu durumun hasta güvenliği ile çalışanların mesleki tatmin ve performansına olumlu yansıdığı belirtilmektedir ${ }^{4-10}$.

Sağlık hizmetlerinin oldukça hayati bir alanı da cerrahi girişim sürecidir. Cerrahi girişim sürecinde bakım, hastanın servise kabulünü, fizyolojik, psikolojik hazırlı̆̆ının yapılarak yaşam fonksiyonlarının kontrol altına alınmasını, sürdürülmesini ve taburcu edilmesini içermektedir ${ }^{11}$. Aktif ve hızlı bu süreçte, ekip çalışmasının önemi yadsınamaz. Cerrahi süreçte yer alan ekip üyeleri; cerrahlar, ameliyathane hemşireleri, cerrahi hemşireleri, anestezi hekimleri, yoğun bakım hemşireleri, anestezi teknikerleri, diyetisyenler, fizik tedavi ve rehabilitasyon uzman hekimleri, fizyoterapistler, fizik tedavi teknikerleri, sosyal hizmet uzmanları, beslenme hemşireleri, psikologlar ve gida mühendisleridir. Bu uzman ekip içerisinde, ekip çalışmasının tam olarak anlaşılamadığ1 veya sağlanamadığı durumlarda iletişim eksiklikleri oluşmakta, hasta ve çalışan güvenliği tehlikeye düşebilmektedir ${ }^{12,13}$. Çalışmalarda hasta güvenliğini tehdit eden faktörlerin başında iletişim eksikliği ve yetersizliği olduğu vurgulanmaktadır ${ }^{14-16}$. Bununla birlikte birbirine karşı güven sağlamamış ekip üyelerinin motivasyonu ile iş doyumlarındaki azalma dikkat çekmektedir ${ }^{17}$. Cerrahi klinikler ve ameliyathanelerde çalışan cerrahi ekip üyeleri arasında olumlu ekip çalışması sergilendiğinde hasta güvenliğinin arttığ1, tıbbi hata oranının azaldığ1, hastaya ilişkin bilgi kaybının olmadığı, tedavi ve bakımda kalitenin arttığ kanıtlanmıştır ${ }^{18,19}$.

Literatür taramasında, yurt dişı ve ülkemizde cerrahi ekip üyelerinin ekip anlayışını ve kişilerarası iletişim tarzlarını belirlemeye yönelik araştırma sayısının yetersiz olduğu görülmüştür. İncelenen çalışmalarda kişilerarası iletişim tarzlarının; öfke, depresyon, yalnızlık, internet bağımlılığı, anksiyete bozuklukları, çocukluk çağı örselenmesi, evlilik uyumu ve cinsel işlev bozuklukları gibi değişkenler ile ele alındığ $1^{2,3,20-}$ 23 görülmüş, tüm cerrahi ekip üyelerini kapsayan bir çalışma ile karşılaşılmamıştır. Bu nedenle çalışma, cerrahi girişim sürecinde yer alan sağllk ekibi üyelerinin kişilerarası ilişki tarzları ve ekip çalışmasına yönelik tutumlarını değerlendirmek amacı ile yapılmıştır.

\section{GEREÇ VE YÖNTEM}

Tanımlayıcı tipte bir çalışma olan bu araştırmanın evrenini Bartın ilinde yer alan devlet hastanesinde çalışan ve cerrahi girişim sürecinde yer alan 153 cerrahi ekip üyesi oluşturdu. Araştırma örneklemi olarak evreni oluşturan cerrahi ekip üyelerinin tamamına ulaşılması hedeflendi. Araştırmanın örneklemini 01.12.2017- 30.12.2017 tarihleri arasında cerrahi klinikler, ameliyathane ve cerrahi yoğun bakımlarda çalışan ve araştırmaya katılmayı kabul eden toplam 126 cerrahi ekip üyesi oluşturdu. Araştırmaya katılmayı kabul etmeyen ve çeşitli nedenlerle kendilerine ulaşılamayan (izinli, istirahatli vb.) ekip üyeleri araştırma kapsamına alınmadı.

Araştırmanın verileri 01.12.2017- 30.12.2017 tarihleri arasında araştırmacı tarafindan Helsinki Deklerasyonu prensiplerine uygun olarak toplandi. Anket doldurma yaklaşık 20 dakika sürdü. Araştırmanın yürütülebilmesi için T.C. Karabük Üniversitesi Girişimsel Olmayan Klinik Araştırmalar Etik Kurul Başkanlı̆̆ı'ndan (01.11.2017 onay tarihli ve $10 / 19$ sayılı karar) ve T.C. Sağlık Bakanlığı Bartın İl Sağlık Müdürlüğü'nden izin alındı. Araştırmada kullanılan ölçekler için gerekli izinler, araştırmaya dahil edilen sağlik profesyonellerinden de araştırmanın amacı ve uygulama hakkında gerekli açıklamalar yapılıp, yazılı onamları alındı. Katılımcıların bireysel bilgilerinin araştırmacı ile 
paylaşıldıktan sonra korunacağı belirtildi. Çalışma sonuçlarının paylaşılacağı iletildi.

\section{Veri toplama araçları}

Çalışmada cerrahi ekip üyelerinin sosyo-demografik özellikleri için "Kişisel Bilgi Formu", iletişim tarzını belirlemek için "Kişilerarası İletişim Tarzları Ölçeği" ve ekip çalışma tutumlarını belirlemek için "Ekip Çalışması Tutumları Ölçeği” kullanıldı.

\section{Kişisel Bilgi Formu}

Katılımcıların sosyo-demografik ve çalışma yaşamlarına ilişkin özelliklerinin belirlenmesi amacıyla literatürler doğrultusunda ${ }^{24-28}$ araştırmacı tarafindan hazırlanmış 7 soruluk "Kişisel Bilgi Formu” dur.

\section{Kişilerarası İletişim Tarzları Ölçeği (KİTÖ)}

Bireylerin kişilerarası iletişim tarzlarını belirlemeyi hedefleyen ve 60 maddeden oluşan bu ölçek, Şahin ve ark. (2007) tarafindan Türk kültürüne özgü olarak geliştirilmiştir ${ }^{2}$. Ölçekte yer alan ifadeler 5 'li likert tipinde olup, ölçekten alınan yüksek puanlar kişilerarası tarzda olumsuzluğa işaret etmektedir. Kişilerarası Tarz Ölçeği "baskın tarz, kaçıngan tarz, öfkeli tarz, duyarsız tarz, manipülatif tarz ve alayc1 tarz" olmak üzere 6 maddeden oluşmaktadır. Ölçeğin Crohnbach Alfa iç tutarlılık katsayısı 0.93'tür. Çalışmamızda ise Crohnbach Alfa iç tutarlılık katsay1s1 0.91'dir.

\section{Ekip Çalışması Tutumları Ölçeği (EÇTÖ)}

Baker ve arkadaşları tarafindan hazırlanan ölçeğin Yardımcı ve arkadaşları yılında Türkiye'de geçerlik güvenirlik çalışmasını gerçekleştirmişlerdir. ${ }^{19,29}$ Ölçek; "ekip yapısı, liderlik, durum izleme, karşılıklı destek ve iletişim" olmak üzere 5 alt bölümden oluşmaktadır. Ölçekte yer alan ifadeler 5'li likert tip olup, ölçekten en az 28, en fazla 140 puan alınabilmektedir. Ölçek puanının yükselmesi bireylerin ekip çalışması tutumların arttı̆̆ını göstermektedir. Ölçeğin Crohnbach Alfa iç tutarlılık katsayısı 0.86 olup, çalışmamızda Crohnbach Alfa iç tutarlilik katsay1s1 0.85 'tir

\section{İstatistiksel analiz}

Verilerin kodlanmas1 ve istatistiksel analizlerde Statistical Package for the Social Sciences 20.0 (SPSS 20.0) paket programı kullanıldı. Çalışmada kategorik değişkenlere ait tanımlayıcı istatistikler yüzde ve sayı ile gösterildi.

Kategorik değişkenler arasındaki ilişkinin belirlenmesinde ki-kare, tek yönlü ve iki yönlü ANOVA testi, ilişkisiz örneklem için t testi ve puan ortalamaları arasındaki farklılığın belirlenmesinde Tukey testi kullanıldı. İstatistiksel analizlerde anlamlılık düzeyi $\mathrm{p}<0.05$ olarak kabul edildi.

\section{BULGULAR}

Katılımcıların \%39.7'sinin 36-45 yaş grubu aralığında, \%61.9'unun kadın, \%73'ünün evli, \%64.3'ünün hemşire, \%22.2'sinin hekim, \%13.5'inin diğer sağlık profesyoneli (Anestezi teknikeri, fizyoterapist, diyetisyen, fizik tedavi teknikeri, sosyal hizmet uzm.) olduğu, \%32.5'inin meslekte çalışma yıllarının 11-20 y1l arası ve \%43.7'sinin şu an çalışmakta oldukları birimde çalışma yıllarının 1-5 yıl arası olduğu belirlendi (Tablo 1).

Çalışmada diğer sağlık profesyonellerinin KİTÖ kaçıngan tarz alt boyutundan aldığ1 puan ortalamalarının hemşirelere göre anlamlı derecede yüksek olduğu ( $p=0.035)$, EÇTÖ iletişim alt boyutu puan ortalamasının hemşire ve hekimlere kıyasla anlamlı derecede yüksek olduğu $(\mathrm{p}=0.013)$ belirlendi. EÇTÖ ve KİTÖ toplam puan ortalamalarından en yüksek puana sahip cerrahi ekip üyesinin diğer sağlık profesyonelleri ve en düşük puana sahip ise hemşireler olduğu bulundu (Tablo 2).

Çalışmada evli ve bekar ekip üyelerinin EÇTÖ toplam puan ortalaması, EÇTÖ durum izlemi ve iletişim alt boyutu puan ortalaması arasında istatistiksel olarak anlamlı fark bulundu $(p<0.05)$. Erkek ve kadın katılımcıların KİTÖ toplam puan ortalaması, kaçıngan tarz ve duyarsız tarz alt boyutu puan ortalamaları ile EÇTÖ'nün liderlik alt boyutu puan ortalaması arasında da istatistiksel olarak anlamlı fark olduğu belirlendi $(\mathrm{p}<0.05)$ (Tablo 3$)$.

Çalışmada sağlık profesyonellerinin meslekte toplam çalışma yılları ile EÇTÖ, KİTÖ ve her iki ölçeğin alt boyutundan aldikları puan ortalamaları arasinda anlamlı bir fark olmamasına karşın, şu anki birimde çalışma süreleri ile KİTÖ’nün baskın tarz alt boyutu puan ortalaması arasında bir ilişki olduğu görüldü $(p<0.05)$. Bu sonuca göre 21 yıl ve üzeri çalışanların puan ortalaması diğer yıllara göre anlamlı derecede yüksektir ( $\mathrm{p}=0.016)$ (Tablo 4). 
Tablo 1. Katılımcıların tanıtıcı özellikleri $(\mathrm{N}=126)$

\begin{tabular}{|c|c|c|}
\hline Özellik & Gruplar & $\mathbf{N}(\%)$ \\
\hline \multirow{4}{*}{ Yaş grubu } & $18-25$ & $13(10.3)$ \\
\hline & $26-35$ & $47(37.3)$ \\
\hline & $36-45$ & $50(39.7)$ \\
\hline & 45 ve üzeri & $16(12.7)$ \\
\hline \multirow[t]{2}{*}{ Cinsiyet } & Erkek & $48(38.1)$ \\
\hline & Kadin & $78(61.9)$ \\
\hline \multirow{2}{*}{$\begin{array}{l}\text { Medeni } \\
\text { durum }\end{array}$} & Evli & $92(73)$ \\
\hline & Bekar & $34(27)$ \\
\hline \multirow{5}{*}{$\begin{array}{l}\text { Eğitim } \\
\text { Durumu }\end{array}$} & Lise & $3(2.4)$ \\
\hline & Ön lisans & $29(23)$ \\
\hline & Lisans & $65(51.6)$ \\
\hline & Yüksek lisans & $11(8.7)$ \\
\hline & Doktora & $18(14.3)$ \\
\hline \multirow{3}{*}{ Meslek } & Hekim (Cerrah, anestezi uzman hekimi ve fizik tedavi rehabilitasyon uzman hekimi) & $28(22.2)$ \\
\hline & Hemșire (Ameliyathane, yoğun bakım, cerrahi servis ve beslenme hemşiresi) & $81(64.3)$ \\
\hline & $\begin{array}{l}\text { Diğer sağlık profesyonelleri (Anestezi teknikeri, fizyoterapist, diyetisyen, fizik tedavi } \\
\text { teknikeri sosyal hizmet uzmanı) }\end{array}$ & $17(13.5)$ \\
\hline \multirow{5}{*}{$\begin{array}{l}\text { Meslekte } \\
\text { çalışma yilı }\end{array}$} & 1 yildan az & $7(5.6)$ \\
\hline & $1-5 \mathrm{y} 1 \mathrm{l}$ & $21(16.7)$ \\
\hline & $6-10 \mathrm{yll}$ & $32(25.4)$ \\
\hline & $11-20$ y1l & $41(32.5)$ \\
\hline & 21 yll ve üzeri & $25(19.8)$ \\
\hline \multirow{5}{*}{$\begin{array}{l}\text { Birimde } \\
\text { çalışma yll }\end{array}$} & 1 yildan az & $19(15.1)$ \\
\hline & $1-5 \mathrm{y} 1 \mathrm{l}$ & $55(43.7)$ \\
\hline & $6-10 \mathrm{y} 1 \mathrm{l}$ & $20(15.9)$ \\
\hline & $11-20$ y1l & $24(19)$ \\
\hline & 21 yll ve üzeri & $8(6.3)$ \\
\hline
\end{tabular}

Tablo 2. Katılımcıların KİTÖ, EÇTÖ ve alt boyutundan aldıkları puanlar

\begin{tabular}{|c|c|c|c|c|c|c|c|c|}
\hline \multirow[t]{2}{*}{ Ölçek } & \multicolumn{2}{|c|}{ Hekim $(n=28)$} & \multicolumn{2}{|c|}{ Hemşire $(n=81)$} & \multicolumn{2}{|c|}{$\begin{array}{l}\text { Diğer Sağlık } \\
\text { Profesyonelleri } \\
(\mathrm{n}=17)\end{array}$} & \multirow[t]{2}{*}{ F } & \multirow[t]{2}{*}{$\mathrm{p}$} \\
\hline & MO & TPO & MO & TPO & MO & TPO & & \\
\hline KİTÖ & 2.04 & 122.25 & 1.92 & 115.44 & 2.08 & 125.06 & 0.870 & 0.421 \\
\hline Baskın Tarz & 1.79 & 25.04 & 1.70 & 23.84 & 1.61 & 22.53 & 0.442 & 0.643 \\
\hline Kaçıngan Tarz & 2.08 & 22.89 & 2.29 & 20.62 & 2.29 & 25.18 & 3.444 & 0.035 \\
\hline Öfkeli Tarz & 2.41 & 21.68 & 1.81 & 19.95 & 2.56 & 23.00 & 1.597 & 0.207 \\
\hline Duyarsız Tarz & 2.11 & 23.18 & 1.99 & 21.88 & 2.11 & 23.18 & 0.585 & 0.559 \\
\hline Manipülatif Tarz & 2.06 & 20.64 & 2.04 & 20.42 & 2.14 & 21.35 & 0.141 & 0.869 \\
\hline $\begin{array}{l}\text { Küçümseyici-Alay } \\
\text { Edici Tarz }\end{array}$ & 1.76 & 8.82 & 1.75 & 8.74 & 1.96 & 9.82 & 0.760 & 0.470 \\
\hline EÇTÖ & 3.64 & 116.32 & 3.63 & 116.01 & 3.70 & 118.47 & 0.442 & 0.644 \\
\hline Ekip Yap1s1 & 3.29 & 26.32 & 3.18 & 25.47 & 3.13 & 25.06 & 1.044 & 0.355 \\
\hline Liderlik & 4.48 & 26.86 & 4.54 & 27.21 & 4.60 & 27.59 & 0.419 & 0.659 \\
\hline Durum İzlemi & 4.32 & 25.93 & 4.33 & 25.96 & 4.44 & 26.65 & 0.526 & 0.592 \\
\hline Karşılıklı Destek & 3.26 & 16.29 & 3.26 & 16.31 & 3.25 & 16.24 & 0.003 & 0.997 \\
\hline İletişim & 4.19 & 20.93 & 4.21 & 21.06 & 4.59 & 22.94 & 4.473 & 0.013 \\
\hline
\end{tabular}

MO: Madde Ortalaması, TPO: Toplam Puan Ortalaması, KITÖ: Kişilerarası İletişim Tarzları Ölçeği, EÇTÖ: Ekip Çalışması Tutumları Ölçeği 
Tablo 3. Katılımcıların medeni durum ve cinsiyet ile KİTÖ, EÇTÖ ve alt boyut puanlarının karşılaştırılması

\begin{tabular}{|c|c|c|c|c|c|c|c|c|c|c|c|c|c|c|}
\hline & & $\begin{array}{l}\text { KİT } \\
\text { ö }\end{array}$ & $\begin{array}{l}\text { Bask1 } \\
\text { n Tarz }\end{array}$ & $\begin{array}{l}\text { Kaçin } \\
\text { gan } \\
\text { Tarz }\end{array}$ & $\begin{array}{l}\text { Öfk } \\
\text { eli } \\
\text { Tarz }\end{array}$ & $\begin{array}{l}\text { Duyar } \\
\text { siz } \\
\text { Tarz }\end{array}$ & $\begin{array}{l}\text { Manipül } \\
\text { atif Tarz }\end{array}$ & $\begin{array}{l}\text { Küçümsey } \\
\text { ici-Alay } \\
\text { Edici Tarz }\end{array}$ & EÇTÖ & $\begin{array}{l}\text { Ekip } \\
\text { Yap1s1 }\end{array}$ & $\begin{array}{l}\text { Liderli } \\
\mathbf{k}\end{array}$ & $\begin{array}{l}\text { Durum } \\
\text { İzlemi }\end{array}$ & $\begin{array}{l}\text { Karşllikl } \\
1 \text { Destek }\end{array}$ & $\begin{array}{l}\text { İletişi } \\
\text { m }\end{array}$ \\
\hline \multirow[t]{2}{*}{ Evli } & $\begin{array}{l}\text { TP } \\
\text { O }\end{array}$ & $\begin{array}{l}120 . \\
76\end{array}$ & 24.72 & 22.22 & $\begin{array}{l}21.0 \\
8\end{array}$ & 22.59 & 21.04 & 9.12 & 115.17 & 25.27 & 26.96 & 25.75 & 16.25 & 20.95 \\
\hline & $\begin{array}{l}\mathrm{M} \\
\mathrm{O}\end{array}$ & 2.01 & 1.77 & 2.02 & 2.34 & 2.05 & 2.1 & 1.82 & 3.6 & 3.16 & 4.49 & 4.29 & 3.25 & 4.19 \\
\hline \multirow[t]{2}{*}{ Bekar } & $\begin{array}{l}\text { TP } \\
\text { O }\end{array}$ & $\begin{array}{l}111 . \\
47\end{array}$ & 21.79 & 20.44 & $\begin{array}{l}19.8 \\
5\end{array}$ & 21.68 & 19.38 & 8.32 & 119.76 & 26.5 & 27.79 & 26.85 & 16.41 & 22.21 \\
\hline & $\begin{array}{l}\mathrm{M} \\
\mathrm{O}\end{array}$ & 1.86 & 1.56 & 1.86 & 2.21 & 1.97 & 1.94 & 1.66 & 3.74 & 3.31 & 4.63 & 4.48 & 3.28 & 4.44 \\
\hline \multicolumn{2}{|l|}{$\mathrm{t}$} & $\begin{array}{l}1.41 \\
8\end{array}$ & 1.678 & 1.238 & $\begin{array}{l}0.85 \\
1\end{array}$ & 0.702 & 1.264 & 1.2 & -2.383 & -1.954 & -1.6 & -2.156 & -0.237 & -2.536 \\
\hline \multicolumn{2}{|l|}{$\mathrm{p}$} & $\begin{array}{l}0.15 \\
9\end{array}$ & 0.096 & 0.218 & $\begin{array}{l}0.39 \\
6\end{array}$ & 0.484 & 0.209 & 0.233 & 0.019 & 0.053 & 0.112 & 0.033 & 0.813 & 0.012 \\
\hline \multirow[t]{2}{*}{ Erkek } & $\begin{array}{l}\text { TP } \\
\text { O }\end{array}$ & $\begin{array}{l}126 . \\
17\end{array}$ & 25.42 & 23.54 & 22 & 24.02 & 21.65 & 9.54 & 115.69 & 25.75 & 26.54 & 25.79 & 16.46 & 21.15 \\
\hline & $\begin{array}{l}\mathrm{M} \\
\mathrm{O}\end{array}$ & 2.1 & 1.82 & 2.14 & 2.44 & 2.18 & 2.17 & 1.91 & 3.62 & 3.22 & 4.42 & 3.68 & 3.29 & 4.23 \\
\hline \multirow[t]{2}{*}{ Kadnn } & $\begin{array}{l}\text { TP } \\
\text { O }\end{array}$ & $\begin{array}{l}113 . \\
38\end{array}$ & 23.01 & 20.63 & $\begin{array}{l}19.9 \\
7\end{array}$ & 21.31 & 19.95 & 8.51 & 116.86 & 25.51 & 27.58 & 26.21 & 16.19 & 21.37 \\
\hline & $\begin{array}{l}\mathrm{M} \\
\mathrm{O}\end{array}$ & 1.89 & 1.64 & 1.88 & 2.22 & 1.94 & 2 & 1.7 & 3.65 & 3.19 & 4.6 & 3.74 & 3.24 & 4.27 \\
\hline $\mathrm{t}$ & & $\begin{array}{l}2.15 \\
6\end{array}$ & 1.506 & 2.253 & $\begin{array}{l}1.55 \\
2\end{array}$ & 2.333 & 1.415 & 1.706 & $\begin{array}{l}-0.652 \\
\end{array}$ & 0.407 & -2.183 & -0.871 & 0.426 & -0.485 \\
\hline $\mathrm{p}$ & & $\begin{array}{l}0.03 \\
3\end{array}$ & 0.135 & 0.026 & $\begin{array}{l}0.12 \\
3\end{array}$ & 0.021 & 0.16 & 0.09 & 0.516 & 0.685 & 0.031 & 0.386 & 0.671 & 0.628 \\
\hline
\end{tabular}

TPO: Toplam Puan Ortalaması MO: Madde Ortalaması KITÖ: Kişilerarası Iletişim Tarzları Ölçeği EÇTÖ: Ekip Çalışması Tutumları Ölçeği

Tablo 4. Katılımcıların mesleki çalı̧̧ma verileri KİTÖ, EÇTÖ ve alt boyut puan ortalaması arasındaki ilişki

\begin{tabular}{|c|c|c|c|c|c|c|c|c|c|c|c|c|c|c|}
\hline & $\begin{array}{l}\text { KIT } \\
\text { Ö }\end{array}$ & Baskın & & $\begin{array}{l}\text { Kaçı } \\
\text { ngan } \\
\text { Tarz }\end{array}$ & $\begin{array}{l}\text { Öfkeli } \\
\text { Tarz }\end{array}$ & $\begin{array}{l}\text { Duyar } \\
\text { siz } \\
\text { Tarz }\end{array}$ & $\begin{array}{l}\text { Manipül } \\
\text { atif Tarz }\end{array}$ & $\begin{array}{l}\text { Küçümsey } \\
\text { ici-Alay } \\
\text { Edici Tarz }\end{array}$ & EÇTÖ & $\begin{array}{l}\text { Ekip } \\
\text { Yap1 } \\
\text { S1 }\end{array}$ & $\begin{array}{l}\text { Liderli } \\
\mathrm{k}\end{array}$ & $\begin{array}{l}\text { Duru } \\
\mathrm{m} \\
\text { İzlemi }\end{array}$ & $\begin{array}{l}\text { Karşılı } \\
\text { klı } \\
\text { Destek }\end{array}$ & $\begin{array}{l}\text { İletişi } \\
\text { m }\end{array}$ \\
\hline \multirow[t]{2}{*}{$\begin{array}{l}<1 \text { yll } \\
(\mathrm{n}=7)\end{array}$} & TPO & 112.14 & $\begin{array}{l}20.4 \\
3 \\
\end{array}$ & 22 & 21 & 21.29 & 18.57 & 8.86 & 118 & $\begin{array}{l}26.2 \\
9 \\
\end{array}$ & 28.43 & 26.86 & 13.86 & 22.57 \\
\hline & MO & 1.87 & 1.46 & 2 & 2.33 & 1.94 & 1.86 & 1.77 & 3.69 & 3.29 & 4.74 & 4.48 & 2.77 & 4.51 \\
\hline \multirow[t]{2}{*}{$\begin{array}{l}1-5 \mathrm{yll} \\
(\mathrm{n}=21)\end{array}$} & TPO & 123.43 & $\begin{array}{l}24.6 \\
2\end{array}$ & $\begin{array}{l}22.7 \\
6\end{array}$ & 20.76 & 22.52 & 22.48 & 10.29 & 114.62 & $\begin{array}{l}24.2 \\
9\end{array}$ & 26.38 & 25.71 & 17.29 & 20.95 \\
\hline & MO & 2.06 & 1.76 & 2.07 & 2.31 & 2.05 & 2.25 & 2.06 & 3.58 & 3.04 & 4.4 & 4.29 & 3.46 & 4.19 \\
\hline \multirow{2}{*}{$\begin{array}{l}6-10 \\
\text { yl } \\
(n=32)\end{array}$} & TPO & 109.13 & $\begin{array}{l}20.5 \\
6\end{array}$ & $\begin{array}{l}19.8 \\
4\end{array}$ & 19.28 & 21.13 & 19.91 & 8.41 & 118.25 & $\begin{array}{l}25.8 \\
4\end{array}$ & 27.19 & 26.34 & 16.88 & 22 \\
\hline & MO & 1.82 & 1.47 & 1.8 & 2.14 & 1.92 & 1.99 & 1.68 & 3.7 & 3.23 & 4.53 & 4.39 & 3.38 & 4.4 \\
\hline \multirow{2}{*}{$\begin{array}{l}11-20 \\
\text { yll } \\
(\mathrm{n}=41)\end{array}$} & TPO & 121.46 & $\begin{array}{l}25.4 \\
1\end{array}$ & $\begin{array}{l}22.5 \\
1\end{array}$ & 21.32 & 22.8 & 20.59 & 8.83 & 115.56 & $\begin{array}{l}25.5 \\
6\end{array}$ & 27.24 & 26.27 & 15.63 & 20.85 \\
\hline & MO & 2.02 & 1.82 & 2.05 & 2.37 & 2.07 & 2.06 & 1.77 & 3.61 & 3.2 & 4.54 & 4.38 & 3.13 & 4.17 \\
\hline \multirow{2}{*}{$\begin{array}{l}21 \text { y1l } \\
\text { ve } \\
\text { üzeri } \\
(\mathrm{n}=25)\end{array}$} & TPO & 122.04 & 26.2 & $\begin{array}{l}21.9 \\
6\end{array}$ & 21.6 & 23.28 & 20.48 & 8.52 & 116.52 & $\begin{array}{l}26.2 \\
8\end{array}$ & 27.4 & 25.36 & 16.48 & 21 \\
\hline & MO & 2.03 & 1.87 & 2 & 2.4 & 2.12 & 2.05 & 1.7 & 3.64 & 3.29 & 4.57 & 4.23 & 3.3 & 4.2 \\
\hline $\mathrm{F}$ & $\begin{array}{l}0.99 \\
4 \\
\end{array}$ & \multicolumn{2}{|l|}{2.31} & 0.79 & 0.484 & 0.513 & 0.68 & 1.192 & 0.576 & $\begin{array}{l}1.33 \\
7 \\
\end{array}$ & 0.931 & 0.877 & 2.058 & 1.59 \\
\hline p & $\begin{array}{l}0.41 \\
4 \\
\end{array}$ & \multicolumn{2}{|l|}{0.062} & $\begin{array}{l}0.53 \\
4 \\
\end{array}$ & 0.748 & 0.727 & 0.607 & 0.318 & 0.681 & $\begin{array}{l}0.26 \\
0 \\
\end{array}$ & 0.448 & 0.480 & 0.090 & 0.181 \\
\hline \multirow{2}{*}{$\begin{array}{l}1 \\
\text { yldan } \\
\text { az } \\
(\mathrm{n}=19) \\
\end{array}$} & TPO & 116.37 & $\begin{array}{l}22.8 \\
4\end{array}$ & $\begin{array}{l}21.9 \\
5\end{array}$ & 19.26 & 22.68 & 20.68 & 8.95 & 117.32 & $\begin{array}{l}25.8 \\
9\end{array}$ & 27.47 & 26,32 & 16 & 21.63 \\
\hline & MO & 1.94 & 1.63 & 2 & 2.14 & 2.06 & 2.07 & 1.79 & 3.67 & 3.24 & 4.58 & 4.39 & 3.2 & 4.33 \\
\hline \multirow{2}{*}{$\begin{array}{l}1-5 \mathrm{yll} \\
(\mathrm{n}=55\end{array}$} & $\begin{array}{l}\text { TP } \\
\mathrm{O}\end{array}$ & $\begin{array}{l}116.2 \\
2\end{array}$ & $\begin{array}{l}22.5 \\
3\end{array}$ & 21.6 & 20.49 & 22.11 & 20.55 & 8.95 & $\begin{array}{l}115.7 \\
5\end{array}$ & $\begin{array}{l}25.0 \\
4\end{array}$ & 26.78 & 26.15 & 16.6 & 21.18 \\
\hline & $\mathrm{MO}$ & 1.94 & 1.61 & 1.96 & 2.28 & 2.01 & 2.06 & 1.79 & 3.62 & 3.13 & 4.46 & 4.36 & 3.32 & 4.24 \\
\hline
\end{tabular}




\begin{tabular}{|c|c|c|c|c|c|c|c|c|c|c|c|c|c|c|}
\hline \multirow{2}{*}{$\begin{array}{l}6-10 \\
y 11 \\
(n=20 \\
)\end{array}$} & $\begin{array}{l}\text { TP } \\
\text { O }\end{array}$ & 115.6 & 22.8 & 21.6 & 20.85 & 21.4 & 20.1 & 8.85 & 116.1 & 25.9 & 27.7 & 25.7 & 15.85 & 20.95 \\
\hline & $\mathrm{MO}$ & 1.93 & 1.63 & 1.96 & 2.32 & 1.95 & 2.01 & 1.77 & 3.63 & 3.24 & 4.62 & 4.28 & 3.17 & 4.19 \\
\hline \multirow{2}{*}{$\begin{array}{l}11-20 \\
y 11 \\
(n=24\end{array}$} & $\begin{array}{l}\text { TP } \\
\mathrm{O}\end{array}$ & $\begin{array}{l}119.1 \\
3 \\
\end{array}$ & $\begin{array}{l}25.9 \\
2 \\
\end{array}$ & 21 & 20.96 & 22.42 & 20.21 & 8.63 & $\begin{array}{l}117.2 \\
9\end{array}$ & 26 & 27.21 & 26.25 & 16.08 & 21.75 \\
\hline & $\mathrm{MO}$ & 1.99 & 1.85 & 1.91 & 2.33 & 2.04 & 2.02 & 1.73 & 3.67 & 3.25 & 4.54 & 4.38 & 3.22 & 4.35 \\
\hline \multirow{2}{*}{$\begin{array}{l}21 \text { yll } \\
\text { ve } \\
\text { üzeri } \\
(n=8)\end{array}$} & $\begin{array}{l}\text { TP } \\
\mathrm{O}\end{array}$ & $\begin{array}{l}140.7 \\
5\end{array}$ & 33 & $\begin{array}{l}24.7 \\
5 \\
\end{array}$ & 25.13 & 25.25 & 23.13 & 9.5 & 117 & $\begin{array}{l}26.8 \\
8 \\
\end{array}$ & 27.88 & 25 & 16.63 & 20.63 \\
\hline & $\mathrm{MO}$ & 2.35 & 2.36 & 2.25 & 2.79 & 2.3 & 2.31 & 1.9 & 3.66 & 3.36 & 4.65 & 4.17 & 3.33 & 4.13 \\
\hline $\mathrm{F}$ & $\begin{array}{l}1.04 \\
9\end{array}$ & 3.181 & & 0.42 & 0.976 & 0.537 & 0.341 & 0.108 & 0.161 & $\begin{array}{l}0.93 \\
9\end{array}$ & 0.707 & 0.518 & 0.269 & 0.531 \\
\hline $\mathrm{p}$ & $\begin{array}{l}0.38 \\
5\end{array}$ & 0.016 & & $\begin{array}{l}0.79 \\
4\end{array}$ & 0.423 & 0.709 & 0.850 & 0.979 & 0.958 & $\begin{array}{l}0.44 \\
4\end{array}$ & 0.589 & 0.723 & 0.898 & 0.713 \\
\hline
\end{tabular}

TPO: Toplam Puan Ortalaması MO: Madde Ortalaması KİTÖ: Kişilerarası İletişim Tarzları Ölçeği EÇTÖ: Ekip Çalışması Tutumları Ölçeği

\section{TARTIŞMA}

Cerrahi ekip, hastanın kaliteli ve bütüncül bakım alması amacıyla bir araya gelmiş uzman sağlık çalışanlarından oluşan bir bütündür. $\mathrm{Bu}$ nedenle çalışmamızın evrenini cerrahi süreçte yer alan tüm sağlık çalışanları oluşturmuştur.

Çalışmada kadın katılımcı oranının yüksek olduğu görülmektedir. Kadın oranının yüksek olmasının nedeni hemşirelerin ekip içinde sayıca fazla yer almaları ve hemşirelik mesleği üyelerinin çoğunlukla kadınlardan oluşması şeklinde açıklanabilir. Literatür incelemesinde cerrahi ekip üyelerinin kişilerarası tarzının belirlenmesine yönelik bir çalıșma ile karşılaşılmazken, diğer sağlık meslek gruplarının kişiler arası iletişimlerini değerlendirmeye ilişkin çalışmalarda, bulgumuza benzer olarak katılımcıların çoğunun kadınların oluşturduğu görülmüştür ${ }^{2,3,20-23}$.

Çalışmada diğer sağlık profesyonellerinin (Anestezi teknikeri, fizyoterapist, diyetisyen, fizik tedavi teknikeri, sosyal hizmet uzmanı) KİTÖ'nün kaçıngan tarz alt boyutundan aldığ1 puan ortalamasının hemşirelere, benzer olarak ölçeğin toplam puan ortalamasının da hemșire ve hekimlere göre anlamlı derecede yüksek olduğu saptanmıştır. Bulguya yönelik yapılan spesifik bir çalışma ile karșılașılmamasına karșın, Hisli Şahin ve arkadașları (2011), kişilerarası ilişkilerinden memnuniyetsiz ya da anksiyete yaşayan katılımcıların KİTÖ'nün kaçıngan tarz alt boyutu ve toplam puan ortalamalarının nispeten daha yüksek olduğunu belirtmişlerdir ${ }^{2}$. Bu durum cerrahi ekibin önemli bir parçasını oluşturan diğer sağlık profesyonellerinin (fizyoterapist, diyetisyen, fizik tedavi teknikeri, anestezi teknikeri ve sosyal hizmet uzmanının) cerrahi süreç içerisinde hekim ve hemşirelere göre daha az aktif görev almaları nedeniyle kaçıngan tarz sergilediklerini akla getirmiştir.

Tüm meslek grupları için iletişimin önemi yadsınamaz bir gerçektir. Ancak sağlık bakım hizmetlerinde ve cerrahi girişim süreçlerinde çalışan profesyoneller açısından iletişim çok daha önemlidir. Ekip içerisinde yaşanan iletişim sorunları, çatışmalar, rol ve görev tanımlarında aksaklıklar ile yetersiz iletişim ekipte tatminsizlik ile mutsuzluğun yanı sıra hastanın tedavi, bakım süreçlerinde gecikmeye, hasta hakkında eksik ya da yanlış bilgi sahibi olmaya, verilen hizmetin kalitesinin düşmesine ve hasta memnuniyetinin azalmasına neden olmaktadır ${ }^{9,10,12}$. Çalıșmamızda diğer sağllk profesyonellerinin EÇTÖ puan ortalamasının hemşire ve hekimlere göre istatistiksel olarak yüksekti. EÇTÖ'nün iletişim alt boyutu puan ortalamasının ise en düşük olduğu meslek grubu hekimlerdi. Ovalı çalışmasında hekimlerin iletişimi gerektiği gibi önemsemediğini, özellikle erkek hekimlerin kadın hekimlere göre iletişimden kaynaklanan sorunlar yaşadığını bulmuştur ${ }^{30}$. Garibağaoğlu ve arkadaşları hekimlerin ekip çalışmasına yönelik tutumlarının istendik seviyede olmamasının tıp eğitiminde ekip çalışmasına değinilmemesinden kaynaklandığını $1^{31}$, Ulusoy ve arkadaşları çalışmasında ekip üyelerinin "ekibin lideri her zaman hekimdir" görüşünde olduklarını belirlemişlerdir". Lafçı ve arkadaşları hekimlerin halen "ekibin lideri hekimdir" anlayışını sürdürdüklerini ifade etmişlerdir ${ }^{27}$. Sexton ve arkadaşları çalışmalarında benzer olarak, cerrahların ekip içinde iletişimlerinin düşük olduğunu belirtmişlerdir ${ }^{8}$. İletişim başarılı ekip çalışmasının temel bileşenidir. Ekip üyelerinin her birinin görevi kendi mesleğine özgü ve birbirinin tamamlayıcısıdır. İletişimin önemsenmediği, sorumluluğun paylaşılmadığ1, ortak karar alma, alınan kararları sorgulayabilme 
becerilerinin geliştirilmediği, bilgi/karar paylaşımı gerektirmediğine inanılan gruplarda hedefe ulaşma hemen hemen imkansızdır. Sağlık hizmeti sunumunda ise bu inanca sahip ekip varllğı tıbbi hata oranının artmasına, hasta ve çalışan güvenliğinin azalmasına, kurum kültürünün zedelenmesine, çalışan ve hasta memnuniyetini olumsuz yönde etkilemesine neden olabilmektedir.

Ekip çalışması tutumlarıyla motivasyon ve iş doyumu arasında anlamlı düzeyde ilişki olduğu bilinmektedir. Ayrıca iş doyumu ve motivasyonla ilgili çalışma şartlarının önemli olduğu yapılan çalışmalarda vurgulanmaktadır ${ }^{8,28,32}$. Çalışmamızda, EÇTÖ toplam puan ortalaması en düşük olan grubu hemşirelerin, en yüksek olan grubu ise diğer sağlık profesyonellerinin oluşturduğu saptanmıştır. Çalışmada cerrahi ekip üyelerinin çalışma şekli (gündüz, gece veya kısmi zamanli) sorgulanmamıştır. Bununla beraber EÇTÖ'den en yüksek puanı alan sağlık personellerinin çok azı olan anestezi teknikerlerinin vardiyalı çalıştığ diğerlerinin ise çoğunlukla gündüz çalıştığ tutumlarını etkileyebileceği düşüncesini akla getirmiştir. Aktif işlem ve girişimleri gerektiren cerrahi girişim sürecinde önemli sorumlulukları yer alan hekim ve hemşirelerin, EÇTÖ puan ortalamasının düșük olarak belirlenmesi, cerrahi işlemlerin yoruculuğu, kapalı alanda kimi zaman oldukça uzun sürede çalışılmasının yarattığı stres ve cerrahi işlem gereklerinin yoruculuğunun neden olabileceğini akla getirmiştir. Cerrahi süreçte cerrah ve hemşireler gibi birincil sorumlukta yer almayan (anestezi teknikerleri hariç) diğer sağlik profesyonelleri olarak gruplandırdığımız sağlık çalışanlarının EÇTÖ puan ortalamasının yüksek olmasinın beklenen bir sonuç olduğu düşünülmektedir.

Çalışmamızda evli katılımcıların EÇTÖ toplam puan ortalamaları, durum izlemi ve iletişim alt boyutu puan ortalamaları bekarlara göre anlamlı derecede düşük olduğu bulunmuştur. Evlilik ve iş yaşamı son yıllarda araştırmalarda sıkça yer almaktadır. Evlilikte rol dengesinin sağlandığı gruplarda bireylerin birbirinin kariyerine olumlu etki sağladığı belirtilmektedir ${ }^{33}$. Bununla birlikte bireylerin, zaman zaman maruz kaldıkları stresörler arasında günlük yaşamlarındaki iş ve aile sorumluluklarını yerine getirme çabasının da olduğu bilinmektedir ${ }^{34}$. Lafçı ve arkadaşları, bekar sağlık personellerinde ekibin çalışmasının yararı puan ortalamasının kısmen daha yüksek olduğunu bulmuşlardır ${ }^{27}$. Doğru ise, yaptığı çalışmada bekar hemşirelerin ekip çalışmasında önemli bir kavram olan motivasyon düzeylerinin daha yüksek olduğunu belirlemiştir $^{35}$. Bu durum evlilikten kaynaklanan aile sorumluluklarını karşılama çabasından bağımsız bekar bireylerin, günlük yaşam enerjilerini daha çok iş yaşamına yönelik sorumluluklarını karşılamaya odakladıklarını akla getirmiştir.

Çalışmamızda erkek katılımcıların KİTÖ toplam puanı ile KİTÖ'nün kaçıngan ve duyarsız tarz alt boyutu puan ortalamasının kadınlara göre anlamlı olarak daha yüksek olduğu belirlenmiştir. Hisli Şahin ve arkadaşları çalışmasında, kişilerarası ilişkilerinden memnuniyetsiz olan bireylerin KİTÖ kaçıngan ve duyarsız tarz alt boyutlarından aldıkları puanların kısmen yüksek olduğu bulunmuştur ${ }^{2}$. Cerrahi ekibi oluşturan erkek üyelerin fazla sayıda yer alan kadın ekip üyelerine göre daha içe dönük tutum sergileyebildiklerini, kişilerarası ilişkilerde memnuniyet düzeylerinin daha düşük olabileceğini akla getirmiştir. Ayrıca araştırmada erkek katılımcıların EÇTÖ'nin liderlik alt boyutu puan ortalamasının kadınlara göre düşük olduğu da görülmüştür. Kadınların erkeklere göre nispeten görev yönetiminde daha başarılı olduklarını, cerrahi kliniklerin çalışma koşullarının hızlı düşünüp doğru karar vermeyi, tıbbi hataların mümkün olan en düşük seviyeye indirgenmesini sağlayacak dikkati ve sürekli hasta güvenliği için ekip üyelerinin birbirinin tamamlayıcısı olmalarını gerektirdiğinden, çalışmamızda katılımcılarının çoğunu oluşturan kadınların liderlik ve ekip çalışması anlayışının öneminin farkında olduklarını da düşündürmüştür.

Lorelei ve arkadaşları çalışmalarında cerrahi ekipte genellikle tekrarlayan süreçlerde iletişimde gerginlik yaşandığını, özellikle stajyer ya da yeni başlayan sağlık ekibi üyelerinin kıdemli çalışanlara soru sormaktan çekindiklerini ve soru sormak yerine kıdemlileri taklit ettiklerini belirtmişlerdir ${ }^{36}$. Sexton ve arkadaşları, sağlık ekibi içinde kıdemli çalışanların iletişime kapalı ve yeni başlayan ekip üyelerinden gelen bildirimlere açık olmadıklarını bildirmişlerdir ${ }^{8}$. Yıldız ve Birgili çalışmalarında, çalıştıkları birimde daha uzun süre çalışan sağlık çalışanının daha düşük motivasyona sahip olduğunu bulmuşlardır ${ }^{37}$. Çalışmamızda çalışılan birimde 21 yıl ve üzeri görev yapan katılımcıların KİTÖ baskın tarz alt boyutu ortalama puanının diğer katılımcılara göre yüksek olduğu görülmüştür. Bu durum cerrahi ekip üyelerinin zaman içinde çalışma performansının, motivasyonun, kişilerarası iletişimden, ekip çalışmasından beklentilerinin azalmasına, diğer yandan aynı birimde 
uzun süre hizmet vermenin sahiplik duygusu ve kıdemli olmanın baskın tarz sergilemelerine neden olabileceği söylenebilir. Çeşitli çalışmalarda, olası risklerin saptanıp önlenmesi, ekip üyelerinin mesleki yeteneklerini özgün bir biçimde sunabilmeleri, güvenli ve etkin çalışma performansı sergileyebilmeleri için geliştirilebilir bazı becerilerin üzerinde çalışılması gerektiği vurgulanmaktadır. Bu becerilerin ise, ekip çalışması, iletişim, liderlik, durumsal farkındalık, karar verme ve problem çözme olduğu, olumlu ekip davranışlarının eğitimle sağlanabildiği belirtilmektedir ${ }^{5,8,9,38}$. Bu anlamda görüldüğü gibi kıdem değil, farkındalık ve eğitimin önemi vurgulanmaktadir.

Çalışmamızın bazı kısıtlılıkları bulunmaktadır. Araştırmanın veri toplama aşamasında çalışma örneklemini oluşturan cerrahi ekip üyelerinin çalışma şekli ve saati sorgulanmamıştır. Bir diğer kısıtlılık ise cerrahi ekibe yönelik iletişim ve ekip çalışmasına yönelik yapılan çalışma sayısının yetersiz olması nedeniyle, istenilen düzeyde tartışılamamış olmasıdır. Çalışmanın güçlü yanı belli bir amaç için bir araya gelmiş ve özel bir grup olan cerrahi ekip üyelerinin kişilerarası iletişim tarzları ve ekip çalışmasını belirleyen bir çalışma ile karşılaşılmamış olmasıdır. Bir diğer güçlü yanı ise çalışmada cerrahi ekip üyelerinin tamamının ele alınmış olması nedeniyle literatürdeki ender çalışmalardan birisidir.

Sonuç olarak çalışmamızda cerrahi ekip üyelerinin kișilerarası iletișim tarzları ile ekip çalıșması tutumlarında anlamlı farklılıklar olduğu belirlenmiştir. $\mathrm{Bu}$ doğrultuda, cerrahi ekip üyelerinin ekip çalışmalarına olumsuz etkisi olan diğer faktörlerin de irdelendiği farklı kurumlarda daha geniş evreni içeren araştırmaların yapılması kanısındayız. Bu doğrultuda, cerrahi ekip üyelerinin kişilerarası iletişim becerilerini ve ekip çalışması tutumlarını geliştirmeye yönelik özel eğitimlerin planlanması ile olumlu tutum sergileyen birimlerin kurum yöneticileri tarafindan ödüllendirilmesi önerilmektedir.

\footnotetext{
Yazar Katkıları: Calısma konsepti/Tasarımı: IIA; Veri toplama: AS; Veri analizi ve yorumlama: AS; Yazı taslağı: AS, IIA; İçeriğin eleştirel incelenmesi: IIA; Son onay ve sorumluluk: AS, IIA; Teknik ve malzeme desteği: AS; Süpervizyon: IIA; Fon sağlama (mevcut ise): yok.

Bilgilendirilmiş Onam: Katılımcılardan yazılı onam alınmıştır. Hakem Değerlendirmesi: Dış bağımsız.

Çıkar Çatışması: Yazarlar çıkar çatışması beyan etmemişlerdir. Finansal Destek: Yazarlar finansal destek beyan etmemişlerdir. Author Contributions: Concept/Design : IIA; Data acquisition: AS; Data analysis and interpretation: AS; Drafting manuscript: AS, IIA; Critical revision of manuscript: IIA; Final approval and accountability: AS, IIA; Technical or material support: AS; Supervision: IIA; Securing funding (if available): $\mathrm{n} / \mathrm{a}$.

Informed Consent: Written consent was obtained from the participants.

Peer-review: Externally peer-reviewed.
}

Conflict of Interest: Authors declared no conflict of interest. Financial Disclosure: Authors declared no financial support

\section{KAYNAKLAR}

1. Arnold C. Theory based perspectives and contemporary dynamics. In interpersonal relationships: professional communication skills for nurses. (Eds: C.Arnold, K Boggs Underman):1-22. Seventh Edition, Elsevier. 2016.

2. Hisli Şahin N, Durak Batıgün A, Koç V. Kișilerarası tarz, kendilik algis1, öfke ve depresyon. Türk Psikiyatri Dergisi. 2011;22:17-25.

3. Durak Batıün A, Hasta D. İnternet bağımlılı̆g: yalnızlık ve kişilerarası ilişki tarzları açısından bir değerlendirme. Anadolu Psikiyatri Dergisi. 2010;11:213-19.

4. İnanç N, Hatipoğlu S, Yurt V. Hemşirelik esasları, Damla Matbaacılık Ltd. Şti. 5.Baskı: 42-58, Ankara, 2000.

5. Hall P, Weawer L. Interdisciplinary education and teamwork: a long and winding road. Medical Education. 2001;35:867-75.

6. Manser T. Teamwork and patient safety in dynamic domains of healthcare: a review of the literature. Acta Anaesthesiol Scand. 2009;53:143-51.

7. Sykes M, Gillerpie B, Chaboyer W, Kang E. Surgical team mapping: implications for staff allocation and coordination. AORN J. 2015;101:238-48.

8. Sexton J, Thomas EJ, Helmreich RL. Error, stres and teamwork in medicine and aviation: crosssectional surveys. BMJ. 2000; 320:745-49.

9. Ulusoy H, Moroğlu Tokgöz D. Hekim ve hemşirelerin ekip çalışmasına ilişskin görüşleri. Pamukkale Tip Dergisi. 2009;2:55-61.

10. Yardımcı F, Başbakkal Z. Tip bilimlerinde ekip kaynak yönetimi. Nobel Med. 2012;8:12-7.

11. Özbayır T. Ameliyat dönemi bakım. (İçinde) Dahili ve cerrahi hastalıklarda bakım (Eds: A Karadakovan, F Eti Aslan) Akademisyen Kitabevi: Ankara, 2014;239277.

12. Atay N. Ameliyathanede ve merkezi sterilizasyon ünitesinde stres, motivasyon, ekip çalışması ve iletişim. 3. Sterilizasyon Ameliyathane Dezenfeksiyon Kongre Kitabı: Marmaris, 2016;85-98.

13. Hu YY, Henrickson Parker S, Lipsitz SR, Arriaga AF, Peyre SE, Corso KA et al. Surgeons' leadership styles and team behavior in operating room. JACS. 2016;1:41-51.

14. Karaöz S. Cerrahi hemşireliği ve etik. Cumhuriyet Üniversitesi Hemşirelik Yüksekokulu Dergisi. 2000;4:1-8.

15. Aren A. Ameliyathanede hasta ve çalışan güvenliği. İstanbul Tip Dergisi. 2008;3:141-45.

16. Ișık Andsoy I. Cerrahi ekibin bilmesi gereken bir konu: ameliyathanelerde yangin riskleri nelerdir? yangın güvenliği nasıl sağlanmalıdır? TAF Preventive Medicine Bulletin. 2013;12:449-54. 
17. Eti Aslan F, Kan Öntürk Z. Güvenli ameliyathane ortamı; biyolojik, kimyasal, fiziksel ve psikososyal riskler, etkileri ve önlemler. Maltepe Üniversitesi Hemşirelik Bilim ve Sanatı Dergisi. 2011;4:133-40.

18. Mazocco K, Petitti D, Fong K, Bonacum D, Brookey J, Graham S et al. Surgical team behaviors and patient outcomes. Am J Surg. 2009;197:678-85.

19. Baker DP, Krokos KJ, Amodeo AM. Team STEPPS attitudes questionnaire manual. agency for healthcare research and quality. Washington DC 20007, October 2008.

20. Özmen Süataç A. Evlilik uyumunun kișilerarası tarz ve öfke açısından araştırılması. Yüksek Lisans Tezi. İzmir, Ege Üniversitesi, 2010.

21. Hisli Şahin N, Durak Batıgün A, Uzun C. Anksiyete bozukluğu: kişilerarası tarz, kendilik algısı ve öfke açısından bir değerlendirme. Anadolu Psikiyatri Derg. 2011;12:107-13.

22. Hisli Şahin N, Durak Batıgün A, Pazvantoğlu Alkan E. Cinsel işlevlerdeki sorunlarda kişilerarası tarz, kendilik algisı ve öfkenin rolü. Türk Psikiyatri Derg. 2012;23:18-25

23. Bilim G. Çocukluk çağı örselenme yaşantıları: duygu düzenleme, kişilerarası tarz ve genel psikolojik sağlık açısından bir inceleme. Yüksek Lisans Tezi. Ankara, Ankara Üniversitesi, 2012.

24. Kumcağız H, Yılmaz M, Balcı Çelik S, Aydın Avcı İ. Hemşirelerin iletişim becerileri: Samsun ili örneği. Dicle Tip Dergisi. 2011;38:49-56.

25. Öğüt A, Kaya D. Sağlık kurumlarında ekip çalıșması. Selçuk Üniversitesi Kadınhanı Faik İçil Meslek Yüksekokulu Sosyal ve Teknik Araştırmalar Dergisi. 2011;1:87-95.

26. Dikmen Y, Yorgun S, Yeşilçam N. Hemşirelerin tıbbi hatalara eğilimlerinin belirlenmesi. Hacettepe Üniversitesi Hemşirelik Fakültesi Dergisi. 2014:44-56.

27. Lafçı D, Pehlivan S, Demiray G. Cerrahi kliniklerinde çalışan hekim ve hemşirelerin ekip çalışmasına ilişkin görüşleri. Sağlık ve Hemşirelik Yönetim Dergisi.
2016;3:55-64.

28. Çelik A, Karaca A. Hemşirelerde ekip çalışması ve motivasyon arasındaki ilişkinin ve etkileyen faktörlerin değerlendirilmesi. Hemşirelikte Eğitim ve Araştırma Dergisi. 2017;14:254-63.

29. Yardımcı F, Başbakkal Z, Beytut D, Muslu G, Ersun A. Ekip çalışması tutumları ölçeğinin geçerlilik ve güvenilirlik çalışması. Anadolu Psikiyatri Derg. 2012;13:131-37.

30. Ovalı F. Hasta güvenliği yaklaşımları. Sağlıkta Performans ve Kalite Dergisi. 2010;1:33-44.

31. Garibağaoğlu M, Saydam R, Gökçay G, Sahip Y. Beslenme sorunu olan çocuklara ekip yaklaşımı ile elde edilen sonuçlar. Turk J Pediatr. 2005;5:109-14.

32. Kundak Z, Üzel Taş H, Keleş A, Eğicioğlu H. Bir üniversite hastanesinde hemşirelik mesleğinde iş tatmini ve motivasyon. Kocatepe Tip Dergisi. 2015;16:1-10.

33. Gürüz D, Temel Eğinli A. İletişim becerileri, Nobel Akademik Yayınclık Eğitim Danışmanlık Tic. Ltd. Şti, 3.Baskı: Ankara, 2013;135-72.

34. Karkoulian S, Srour J, Sinan T. A gender perspective on work-life balance, perceived stress, and locus of control. J Bus Res. 2016;69:4918-23.

35. Doğru E. İstanbul ilinde özel bir hastane grubunda çalışan yoğun bakım hemşirelerinin motivasyon düzeylerinin belirlenmesi. Yüksek Lisans Tezi. İstanbul, Haliç Üniversitesi, 2010.

36. Lorelei L, Reznick R, Espin S, Glenn R, De Vito I. Team communications in the operating room: talk patterns, sites of tension, and implications for novices. Academic Medicine. 2002;77:232-37.

37. Yıldız M, Birgili F. Muğla ve Menteşe devlet hastaneleri yoğun bakım servislerinde çalıșan hemşirelerin motivasyon düzeylerinin belirlenmesi. Yoğun Bakım Hemşireliği Dergisi. 2007;11:1-9.

38. Kemper PF, Wagner C, Bruijne MD. Implementation of crew resource management: a qualitative study in 3 intensive care units. J Patient Saf. 2017;13:223-31. 